J Am Chem Soc. 2011 June 22; 133(24): 9228-9231. doi:10.1021/ja203034k.

\title{
Total Synthesis of Bryostatin 9
}

\author{
Paul A. Wender ${ }^{*}$ and Adam J. Schrier \\ Departments of Chemistry and Chemical and Systems Biology, Stanford University, Stanford, CA \\ 94305-5080
}

\section{Abstract}

The total synthesis of bryostatin 9 was accomplished using a uniquely step economical and convergent Prins-driven macrocyclization strategy. At 25 linear and 42 total steps, this is currently the most concise and convergent (5 steps post fragment coupling) synthesis of a potent bryostatin.

The bryostatins are a family of 20 structurally complex natural products ${ }^{1}$ putatively produced by a bacterial symbiont ${ }^{2}$ of the marine bryozoan Bugula neritina. Extracts of this organism were found to have potent anticancer activity by Pettit and coworkers in $1968,{ }^{3}$ but it was not until 1981 that the structure of bryostatin 1, the prototypical member of this family, was elucidated (Figure 1). ${ }^{4}$ Structurally characterized by a 20 -member macrolactone core containing three densely functionalized pyran ring motifs, members of this family differ primarily in the identity (or absence) of acyloxy substituents at positions 7 and 20. Additional diversity is observed in the C-ring pyran substructure: bryostatins 16 and 17 contain a dihydropyran C-ring in lieu of the more common tetrahydropyran, and bryostatins 3 and 20 possess a C22-oxygen that engages the C21-exocyclic enoate as part of a butenolide motif.

The bryostatins exhibit a uniquely rich and diverse portfolio of biological activities. Bryostatin 1, the most thoroughly investigated congener, has been found to restore apoptotic function in cancer cells, ${ }^{5}$ stimulate the immune system, ${ }^{6}$ and reverse multidrug resistance. In anticancer clinical trials, ${ }^{7}$ bryostatin 1 has demonstrated the ability to enhance the activities of known oncolytic agents at remarkably low doses $\left(\sim 50 \mu \mathrm{g} / \mathrm{m}^{2}\right) .{ }^{8}$ Of further significance, bryostatin 1 has been shown to induce the formation of synapses, ${ }^{9}$ improve memory and learning in animal models, ${ }^{10}$ and enhance the $\alpha$-secretase processing of amyloid precursor protein, ${ }^{11}$ suggesting its possible use as a novel Alzheimer's disease ${ }^{12}$ or post-stroke ${ }^{13}$ therapeutic. These activities are believed to result at least in part from bryostatin's extraordinary affinity for Protein Kinase C (PKC) and other C1-domain containing proteins. ${ }^{14}$

Impressive total syntheses of five bryostatins have been reported (Fig. 1): bryostatin 7 in 1990 by Masamune and coworkers, ${ }^{15}$ bryostatin 2 in 1998 by Evans and coworkers (a formal synthesis of bryostatin 1), ${ }^{16}$ bryostatin 3 in 2000 by Yamamura and coworkers, ${ }^{17}$ bryostatin 16 in 2008 by Trost and Dong, ${ }^{18}$ and, most recently, bryostatin 1 by Keck and coworkers. ${ }^{19}$ Additionally, a formal total synthesis of bryostatin 7 was reported by Hale and colleagues in $2006 .{ }^{20}$ Several additional groups have also made noteworthy contributions to this field, including those of Thomas, ${ }^{21}$ Vandewalle, ${ }^{22}$ Roy, ${ }^{23}$ Burke, ${ }^{24}$ Krische, ${ }^{25}$ Hoffmann, ${ }^{26}$ Yadav, ${ }^{27}$ and others. ${ }^{28}$

wenderp@stanford.edu.

SUPPORTING INFORMATION PARAGRAPH

Experimental procedures and spectral data. This material is available free of charge via the Internet at http://pubs.acs.org. 
Of those bryostatins that have been prepared by total synthesis, bryostatins $1,2,3$, and 7 are highly potent ligands for PKC $\left(K_{\mathrm{i}}<10 \mathrm{nM}^{29}\right)$. Each congener contains a C-ring tetrahydropyran motif with attendant C19-hemiketal and C20-acyloxy groups. Bryostatin 16, which lacks these structural elements, is much less active $\left(\mathrm{PKC} \alpha K_{\mathrm{i}}=118 \mathrm{nM}\right)$. While the early syntheses reported by Masamune, Evans and Yamamura provided a starting point for accessing the potent bryostatins, further development of these routes has not been reported, thus limiting their current impact on supply due to their lengths (42-45 LLS, >75 total steps). In addition, the points of convergence of these syntheses necessitate a further 14-21 linear steps to elaborate each target following assembly of their respective pyran-containing backbones, thus limiting step economical access to diverse analogs.

Keck's synthesis of bryostatin 1, requiring 31 linear and an estimated 57 total steps, is a notable advance. ${ }^{19}$ This strategy utilized an intermolecular Prins cyclization to anneal the Bring, which was then followed by 11 additional steps to elaborate the macrocycle (via lactonization) and other peripheral functionality.

In 1988, in collaboration with the groups of Pettit and Blumberg, we advanced a computerbased structure/function hypothesis in which the northern A/B-ring architecture of bryostatin is proposed to conformationally restrict the southern fragment functionality required for effective recognition by PKC. ${ }^{30}$ This analysis guided our design of the first simplified, functional analogs of bryostatin, ${ }^{31}$ exemplified by $\mathbf{1}$ (Figure 2), ${ }^{32}$ which demonstrated that bryostatin-like potency can be achieved and even exceeded with great simplification of northern fragment functionality. Strategically, a design element common to this and numerous related bioactive analogs ${ }^{33}$ was the incorporation of a dioxane B-ring as a pyran surrogate, which enabled macrocycle assembly by esterification and subsequent macroacetalization of a diol-acid northern fragment with an aldehyde-containing southern fragment to produce in sequence the ester (lactone) and B-ring dioxane under mild conditions (Fig. 2A). By avoiding challenging late-stage $\mathrm{C}-\mathrm{C}$ bond forming processes, fully functionalized coupling partners could be employed, which enabled excellent overall convergence (e.g. 1 is accessed in only 1 step following fragment coupling).

Recently, we reported that this convergent strategy accommodates a Prins-driven macrocyclization (Fig. 2B) in place of the macro-acetalization reaction to provide the corresponding B-ring tetrahydropyran architecture, exemplified by analogs $\mathbf{2}$ and $3{ }^{34}$ Like the macro-acetalization precedent, this mild macrocyclization tolerates the sensitive C-ring functionality of precursor fragments, thereby enabling the synthesis of $\mathbf{2}$ in only 3 steps following esterification of a hydroxyallylsilane-containing northern piece with the same aldehyde-containing southern fragment employed in the synthesis of $\mathbf{1}$.

While the excellent PKC affinity and bioactivity of 1-3 and related analogs supports a scaffolding role of bryostatin's northern A/B-ring motif, recent work by our group and Keck's group has demonstrated that additional structure/function relationships are associated with this region. For example, we have found that $\mathrm{A} /$ Bring structure variation influences PKC isoform selectivity, ${ }^{35}$ and Keck, Blumberg, and coworkers have found that A-ring modifications influence activity against certain cancer cell lines. ${ }^{36}$

Prompted by the importance of elucidation of these structure-function-selectivity relationships, the therapeutic potential of these agents, and the scarcity of the natural products, we sought a facile, maximally convergent route to variably and systematically functionalized northern fragment analogs. Our designed analogs included those that possess the full complement of functionality present in the natural product family, a largely unexplored area due to scarce supply. Toward this end, we report herein the first total synthesis of bryostatin 9 . This natural product has excellent affinity for PKC $\left(K_{\mathrm{i}}=1.3 \mathrm{nM}\right)$ 
and was first isolated in $1986^{37}$ by Pettit and coworkers in $2.7 \cdot 10^{-5} \%$ yield. Our synthesis proceeds in 25 linear steps using a Prins-driven macrocyclization strategy. This is the most step economical and convergent total synthesis of a potent bryostatin (PKC $K_{\mathrm{i}}<10 \mathrm{nM}$ ), underscoring the strategic value of this functionality-tolerant macrocyclization reaction. ${ }^{38}$ Recent notable examples of Prins macrocyclizations have also been described by the Scheidt, ${ }^{39}$ Lee, ${ }^{40}$ Rychnovsky, ${ }^{41}$ and Yadav groups. ${ }^{42}$

With this disconnection approach, the synthesis of bryostatin 9 was simplified to accessing hydroxyallylsilane-containing northern fragment $\mathbf{4}$ and aldehyde-containing southern fragment $\mathbf{5}$. The synthesis of $\mathbf{4}$ commenced with the benzylation of C1-C9 lactone $\mathbf{6}$ (Scheme 1A), a versatile A-ring intermediate available in 7 steps from acrolein that we had previously disclosed for the synthesis of several A-ring bryologs. ${ }^{35 \mathrm{~b}}$ The $\mathrm{C} 10-\mathrm{C} 13$ carbon fragment was installed by addition of the ethyl acetoacetate dienolate, and equilibration of the resulting C9 lactol epimers to the anomeric methyl ketal was accomplished using PPTS in $\mathrm{MeOH}$. Reduction of $\mathrm{C} 11$ with $\mathrm{NaBH}_{4}$ favored hydroxyester 8 ( $\mathrm{dr}$ 78:22), which was isolated in $61 \%$ yield.

Silylation and double nucleophilic addition ${ }^{43}$ of $\mathrm{TMSCH}_{2} \mathrm{MgCl}$ mediated by $\mathrm{CeCl}_{3} \cdot 2 \mathrm{LiCl}^{44}$ then provided tertiary alcohol $\mathbf{1 0}$. We found that Knochel's soluble cerium salt provided the optimal yield (65\%) for this challenging reaction; use of conventionally-dried anhydrous $\mathrm{CeCl}_{3}$ (from its heptahydrate) gave poorer yields (typically $\sim 45-50 \%$ ) of a less pure product. Peterson olefination of $\mathbf{1 0}$ with NaHMDS furnished the corresponding allylsilane.

Debenzylation was cleanly effected using the lithium naphthalenide reagent to provide C1,C7-diol 11 in 87\% yield, and the $\mathrm{C} 1$ hydroxyl group was oxidized to its corresponding carboxylic acid using a combined TEMPO/PhI $(\mathrm{OAc})_{2} / \mathrm{NaClO}_{2}$ system. Acetylation of this product followed by alkaline aqueous workup provided the fully elaborated northern fragment 4 in 57\% yield over 2 steps and in $2 \%$ overall yield over a 17 -step sequence.

The bryostatin 9 southern fragment 5 was prepared from olefin 12 (Scheme 1B), ${ }^{32}$ an intermediate available in 8 steps from 2,2-dimethyl-1,3-proanediol that we had developed for the synthesis of analogs 1-3. Ozonolysis provided the corresponding ketoaldehyde, which was then chemoselectively olefinated using Takai's protocol ${ }^{45}$ to provide a 93:7 mixture of $E$ - and $Z$-ethylidene isomers 13. Although these isomers were not separable via chromatography at this or subsequent stages, the undesired Z-component was ultimately removed in the dihydroxylation step (vide infra).

Aldol condensation of $\mathbf{1 3}$ with methyl glyoxylate installed the $\mathrm{C} 21$-enoate motif in $81 \%$ yield, and reduction with $\mathrm{NaBH}_{4} / \mathrm{CeCl}_{3}$ followed by butanoylation provided ester 14 in $91 \%$ yield over 2 steps. Desilylation with $3 \mathrm{HF} \cdot \mathrm{Et}_{3} \mathrm{~N}$ followed by Dess-Martin oxidation then gave a $\mathrm{C} 17$ aldehyde that was homologated in one step to unsaturated aldehyde $\mathbf{1 5}$ by nucleophilic addition of the zincate reagent derived from Z-2-lithio-1-ethoxyethylene and dimethylzinc followed by acidic aqueous workup.

At this stage, the $\mathrm{C} 25 / \mathrm{C} 26-(R, R)$ diol subunit was installed with $83: 17$ d.r. and $78 \%$ combined yield via Sharpless' dihydroxylation. The undesired C25/C26-Z-olefin carried through to this point ( $\sim 7 \mathrm{~mol} \%)$ was less reactive under these conditions; recovered starting material was enriched in this isomer. ${ }^{46}$ The $(R, R) /(S, S)$ glycol mixture was then subjected to aqueous $p$-Ts $\mathrm{OH}$ to hydrolyze the $\mathrm{C} 19$ methyl ketal, and selective silylation of the $\mathrm{C} 26$ hydroxyl group provided recognition domain 5 as a single diastereomer in 64\% yield over 2 steps. This domain was thereby accessed in $\sim 2 \%$ yield over a 19-step longest linear sequence. Esterification of $\mathbf{5}$ with an equivalent of northern fragment $\mathbf{4}$ proceeded in $82 \%$ yield using Yamaguchi's protocol (Scheme 2), thus setting the stage for the Prins macrocyclization. 
In our previous report detailing the syntheses of $\mathbf{2}$ and $\mathbf{3},{ }^{34}$ the triethylsilyl-protected macrocyclization precursor analogous to $\mathbf{1 7}$ was desilylated and the corresponding hydroxyallylsilane was cyclized using TMSOTf in $\mathrm{Et}_{2} \mathrm{O} .{ }^{47}$ However, for functionalized Aring substrates more closely related to $\mathbf{1 7}$ those conditions yielded a significant amount of a spirocyclic byproduct that resulted from C9 methyl ketal activation. ${ }^{48}$ We therefore investigated alternative reaction conditions and found that treatment of $\mathbf{1 7}$ with catalytic PPTS in anhydrous $\mathrm{MeOH}$ provided, in a single step, macrocyclization product $\mathbf{1 8}$ (65\% yield). Notably, these mild conditions obviate the need for a separate C11-desilylation step as the reactive hydroxyallylsilane is revealed in situ.

The exocyclic B-ring enoate motif was then installed in a two-step process; oxidative cleavage of the $\mathrm{C} 13$-methylidene with stoichiometric ozone proceeded in $72 \%$ yield, and olefination of the resulting ketone was accomplished in $82 \%$ combined yield via HornerWadsworth-Emmons olefination with $(R)$-BINOL-derived phosphonoacetate 19. ${ }^{49}$ The 79:21 Z:E selectivity of this olefination is in good accord with that observed by Evans, Yamamura, and Keck. The substrate-controlled reaction with trimethyl phosphonoacetate lacked appreciable selectivity (48:52 Z:E).

Global desilylation and C9-ketal hydrolysis was accomplished in two steps and 76\% combined yield by treatment of enoate mixture $\mathbf{2 0}$ with HF.pyridine followed by aqueous PPTS,${ }^{50}$ thereby providing pure bryostatin 9 in $52 \%$ yield.

We conclusively established the identity of our synthetic material by comparison with an authentic sample kindly provided by Prof. G. R. Pettit. As has been reported for bryostatin $1,{ }^{51}$ we observed that several ${ }^{1} \mathrm{H}$ NMR chemical shifts for bryostatin 9 are strongly concentration-dependent in certain aprotic solvents $\left(\mathrm{CDCl}_{3}, \mathrm{C}_{6} \mathrm{D}_{6}\right)$. This was not observed in $\mathrm{CD}_{3} \mathrm{OD}$, in which excellent spectral overlay was obtained between the synthetic and authentic material. All other analytical data for the synthetic sample were found to be in agreement with published or observed data for the natural product (See Supporting Information).

This synthesis provided bryostatin 9 in 25 linear and 42 total steps. Significantly, fragment syntheses are readily scaled to produce gram quantities of advanced intermediates which due to the potency of these agents has clinical supply potential. This approach enables access to the complete and highly functionalized bryostatin oxycarbocyclic ring system (e.g. 18) in only 2 steps from similarly complex northern and southern fragments $\mathbf{4}$ and $\mathbf{5}$. More generally, the macro-Prins and macroacetalization strategies provide potentially general and functional group tolerant approaches to natural or unnatural pyran-containing macrocycles and their dioxane analogs. The flexibility, convergence, scalability and step economy of these strategies enable access to natural and designed bryostatin analogs that are critically needed for ongoing mode of action, structural and preclinical studies.

\section{Supplementary Material}

Refer to Web version on PubMed Central for supplementary material.

\section{Acknowledgments}

Financial support of this work provided by the NIH (CA31845) is gratefully acknowledged. AJS was supported by an Eli Lilly graduate fellowship. We thank Dr. G. R. Pettit for providing an authentic sample of bryostatin 9 for analytical purposes. 


\section{References}

1. For pertinent reviews of the chemistry and biology of the bryostatins, see: (a) Mutter R, Willis M. Biorg Med Chem. 2000; 8:1841-1860.(b) Hale KJ, Hummersone MG, Manaviazar S, Frigerio M. Nat Prod Rep. 2002; 19:413-453. [PubMed: 12195811]

2. For an excellent lead reference, see: Trindade-Silva AE, Lim-Fong GE, Sharp KH, Haygood MG. Curr Opin Biotechnol. 2010; 21:834-842. [PubMed: 20971628]

3. Pettit GR, Day JF, Hartwell JL, Wood HB. Nature. 1970; 227:962-963. [PubMed: 4393654]

4. Pettit GR, Herald CL, Doubek DL, Herald DL, Arnold E, Clardy J. J Am Chem Soc. 1982; 104:6846-6848.

5. Wall NR, Mohammad RM, Al-Katib AM. Leuk Res. 1999; 23:881-888. [PubMed: 10573132]

6. For a recent study and lead references, see: Shaha SP, Tomic J, Shi Y, Pham T, Mero P, White D, He L, Baryza JL, Wender PA, Booth JW, Spaner DE. Clin Exp Immunology. 2009; 158:186-198.

7. Kortmansky J, Schwartz GK. Cancer Invest. 2003; 21:924-936. [PubMed: 14735696] For current information, see: (b) http://clinicaltrials.gov

8. For a recent study and lead references, see: (a) Barr PM, Lazarus HM, Cooper BW, Schluchter MD, Panneerselvam A, Jacobberger JW, Hsu JW, Janakiraman N, Simic A, Dowlati A, Remick SC. Am J Hematol. 2009; 84:484-487. [PubMed: 19536846] (b) Ajani JA, Jiang Y, Faust J, Chang BB, Ho L, Yao JC, Rousey S, Dakhil S, Cherny RC, Craig C, Bleyer A. Invest New Drugs. 2006; 24:353357. [PubMed: 16683077]

9. Hongpaisan J, Alkon DL. Proc Natl Acad Sci USA. 2007; 104:19571-19576. [PubMed: 18073185]

10. Sun MK, Alkon DL. Eur J Pharm. 2005; 512:43-51.

11. Etcheberrigaray R, Tan M, Dewachter I, Kuiperi C, Van der Auwera I, Wera S, Qiao L, Bank B, Nelson TJ, Kozikowski AP, Van Leuven F, Alkon DL. Proc Natl Acad Sci USA. 2004; 101:11141-11146. [PubMed: 15263077]

12. (a) Sun MK, Alkon DL. Arch Pharm Chem. 2009; 342:689-698.(b) Khan TK, Nelson TJ, Verma VA, Wender PA, Alkon DL. Neurobiol Dis. 2009; 34:332-339. [PubMed: 19233276]

13. (a) Sun MK, Hongpaisan J, Nelson TJ, Alkon DL. Proc Natl Acad Sci USA. 2008; 105:1362013625. [PubMed: 18768786] (b) Sun MK, Hongpaisan J, Alkon DL. Proc Natl Acad Sci USA. 2009; 106:14676-14680. [PubMed: 19667190]

14. (a) Kazanietz MG. Mol Pharmacol. 2002; 61:759-767. [PubMed: 11901214] For a recent study on bryostatin and bryolog activation of RasGRP, see: (b) Stang SL, Lopez-Campistrous A, Song X, Dower NA, Blumberg PM, Wender PA, Stone JC. Exp Hematol. 2009; 37:122-134. [PubMed: 19100522]

15. Kageyama M, Tamura T, Nantz MH, Roberts JC, Somfai P, Whritenour DC, Masamune S. J Am Chem Soc. 1990; 112:7407-7408.

16. Evans DA, Carter PH, Carreira EM, Charette AB, Prunet JA, Lautens M. J Am Chem Soc. 1999; 121:7540-7552.

17. Ohmori K, Ogawa Y, Obitsu T, Ishikawa Y, Nishiyama S, Yamamura S. Angew Chem Int Ed. 2000; 39:2290-2294.

18. (a) Trost BM, Dong G. Nature. 2008; 456:485-488. [PubMed: 19037312] (b) Trost BM, Dong G. J Am Chem Soc. 2010; 132:16403-16416. [PubMed: 21043491]

19. Keck GE, Poudel YB, Cummins TJ, Rudra A, Covel JA. J Am Chem Soc. 2011; 133:744-747. [PubMed: 21175177]

20. (a) Hale KJ, Frigerio M, Manaviazar S. Org Lett. 2003; 5:503-505. [PubMed: 12583754] (b) Manaviazar S, Frigerio M, Bhatia GS, Hummersone MG, Aliev AE, Hale KJ. Org Lett. 2006; 8:4477-4480. [PubMed: 16986929]

21. (a) Allen JV, Green AP, Hardy S, Heron NM, Lee ATL, Thomas EJ. Tetrahedron Lett. 2008; 49:6352-6355.(b) Ball M, Bradshaw BJ, Dumeunier R, Gregson TJ, MacCormick S, Omori H, Thomas EJ. Tetrahedron Lett. 2006; 47:2223-2227.

22. De Brabander J, Vandewalle M. Pure Appl Chem. 1996; 68:715-718.

23. Roy R, Rey AW, Charron M, Molino R. Chem Commun. 1989:1308-1310. 
24. (a) Voight EA, Seradj H, Roethle PA, Burke SD. Org Lett. 2004; 6:4045-4048. [PubMed: 15496095] (b) Voight EA, Roethle PA, Burke SD. J Org Chem. 2004; 69:4534-4537. [PubMed: 15202915]

25. (a) Lu Y, Krische MJ. Org Lett. 2009; 11:3108-3111. [PubMed: 19586066] (b) Cho CW, Krische MJ. Org Lett. 2006; 8:891-894. [PubMed: 16494467]

26. Vakalopoulos A, Lampe TJF, Hoffmann HMR. Org Lett. 2001; 3:929-932. [PubMed: 11263918]

27. Yadav JS, Bandyopadhyay A, Kunwar AC. Tetrahedron Lett. 2001; 42:4907-4911.

28. For a review of synthetic approaches, see: Hale KJ, Manaviazar S. Chem Asian J. 2010; 5:704754.

29. $\mathrm{PKC} \mathrm{K}_{\mathrm{i}}$ 's are for a mouse-brain isoform mixture, see Ref 30

30. Wender PA, Cribbs CM, Koehler KF, Sharkey NA, Herald CL, Kamano Y, Pettit GR, Blumberg PM. Proc Natl Acad Sci USA. 1988; 85:7197-7201. [PubMed: 3174627]

31. (a) Wender PA, De Brabander J, Harran PG, Jiminez JM, Koehler MFT, Lippa B, Park CM, Shiozaki M. J Am Chem Soc. 1998; 120:4534-4535.(b) Wender PA, De Brabander J, Harran PG, Jiminez JM, Koehler MFT, Lippa B, Park CM, Siedenbiedel C, Pettit GR. Proc Natl Acad Sci USA. 1998; 95:6625-6629.

32. Wender PA, Baryza JL, Bennett CE, Bi FC, Brenner SE, Clarke MO, Horan JC, Kan C, Lacôte E, Lippa BS, Nell PG, Turner TM. J Am Chem Soc. 2002; 124:13648-13649. [PubMed: 12431074]

33. Wender, PA.; Baryza, JL.; Hilinski, MK.; Horan, JC.; Kan, C.; Verma, VA. Beyond Natural Products: Synthetic Analogues of Bryostatin 1. In: Huang, Z., editor. Drug Discovery Research: New Frontiers in the Post-Genomic Era. Wiley-VCH; Hoboken, NJ: 2007. p. 127-162.

34. Wender PA, DeChristopher BA, Schrier AJ. J Am Chem Soc. 2008; 130:6658-6659. [PubMed: 18452292]

35. (a) Wender PA, Verma VA. Org Lett. 2006; 8:1893-1896. [PubMed: 16623578] (b) Wender PA, Baryza JL, Brenner SE, DeChristopher BA, Loy BA, Schrier AJ, Verma VA. Proc Natl Acad Sci USA. 2011; 108:6721-6726. [PubMed: 21415363]

36. (a) Keck GE, Kraft MB, Truong AP, Li W, Sanchez CC, Lewin NE, Blumberg PM. J Am Chem Soc. 2008:6660-6661. [PubMed: 18452293] (b) Keck GE, Poudel YB, Welch DS, Kraft MB, Truong AP, Stephens JC, Kedei N, Lewin NE, Blumberg PM. Org Lett. 2009; 11:593-596. [PubMed: 19113896] (c) Keck GE, Li W, Kraft MB, Kedei N, Lewin NE, Blumberg PM. Org Lett. 2009; 11:2277-2280. [PubMed: 19419164] (d) Keck GE, Poudel YB, Rudra A, Stephens JC, Kedei N, Lewin NE, Peach ML, Blumberg PM. Angew Chem Int Ed. 2010; 49:4580-4584.

37. Pettit GR, Kamano Y, Herald CL. J Nat Prod. 1986; 49:661-664. [PubMed: 3783162]

38. For a review of this macrocyclization strategy, see: Crane EA, Scheidt KA. Angew Chem Int Ed. 2010; 49:8613-8326.

39. (a) Custar DW, Zabawa TP, Scheidt KA. J Am Chem Soc. 2008; 130:804-805. [PubMed: 18161979] (b) Custar DW, Zabawa TP, Hines J, Crews CM, Scheidt KA. J Am Chem Soc. 2009; 131:12406-12414. [PubMed: 19663512]

40. (a) Woo SK, Kwon MS, Lee E. Angew Chem Int Ed. 2008; 47:3242-3244.(b) Woo SK, Lee E. J Am Chem Soc. 2010; 132:4564-4565. [PubMed: 20222708]

41. (a) Bahnck KB, Rychnovsky SD. J Am Chem Soc. 2008; 130:13177-13181. [PubMed: 18767844]

(b) Gesinski MR, Tadpetch K, Rychnovsky SD. Org Lett. 2009; 11:5342-5345. [PubMed: 19873984]

42. (a) Yadav JS, Kumar GGKSN. Tetrahedron. 2010; 66:480-487.(b) Yadav JS, Pattanayak MR, Das PP, Mohapatra DK. Org Lett. 2011; 13:1710-1713. [PubMed: 21388179]

43. Narayanan BA, Bunnelle WH. Tetrahedron Lett. 1987; 28:6261-6264.

44. Krasovskiy A, Kopp F, Knochel P. Angew Chem Int Ed. 2006; 45:497-500.

45. Okazoe T, Takai K, Utimoto K. J Am Chem Soc. 1987; 109:951-953.

46. (a) Kolb HC, VanNieuwenhze MS, Sharpless KB. Chem Rev. 1994; 94:2483-2587.For a related example, see: (b) Smith AB III, Verhoest PR, Minbiole KP, Schelhaas M. J Am Chem Soc. 2001; 123:4834-4836. [PubMed: 11457294] footnote 13

47. (a) Marko IE, Mekhalfia A. Tetrahedron Lett. 1992; 33:1799-1802.(b) Keck GE, Covel JA, Schiff T, Yu T. Org Lett. 2002; 4:1189-1192. [PubMed: 11922815] 
48. Analogous reactivity was also observed by Keck and coworkers for similar substrates in an intermolecular Prins approach, see Ref. 19.

49. Tanaka K, Ohta Y, Fuji K. Terahedron Lett. 1993; 34:4071-4074.(b) For application of this reagent in bryostatin synthesis, see: Refs. 16, 17, 19.

50. The latter step was required to hydrolyze C9-fluoride products that formed during desilylation. For a related example, see: Costello BJ, Driver MJ, MacLachlan WS, Taylor AW. J Chem Soc Perkin Trans. 1993; 1:1829-1830.

51. Pettit GR, Leet JE, Herald CL, Kamano Y, Boettner FE, Baczynskyj L, Nieman RA. J Org Chem. 1987; 52:2854-2860.(b) See also Ref. 19. 


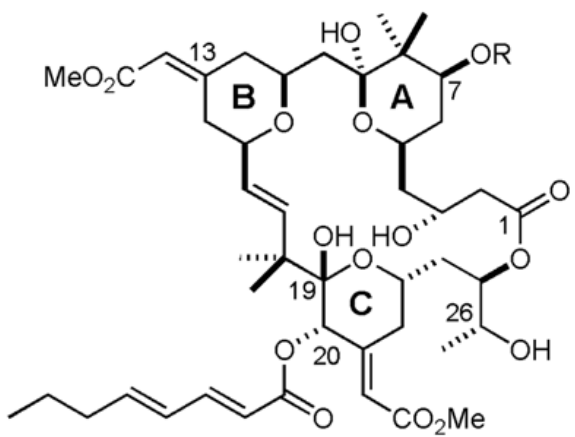

Bryostatin 1: $\mathrm{R}=\mathrm{Ac} ; \mathrm{PKC} K_{\mathrm{i}}=1.4 \mathrm{nM}$ Bryostatin 2: $\mathrm{R}=\mathrm{H} ; \quad \mathrm{PKC} K_{\mathrm{i}}=5.9 \mathrm{nM}$

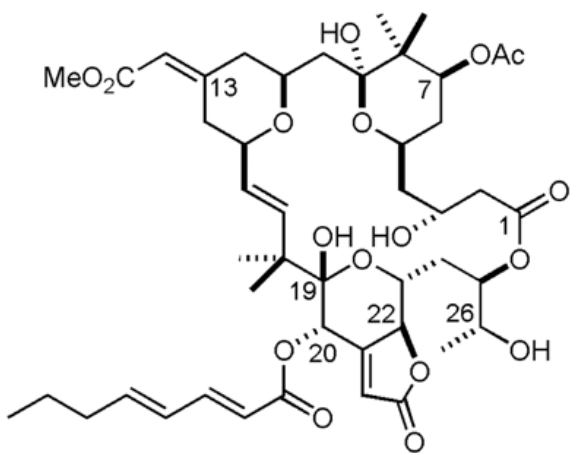

Bryostatin 3: $\mathrm{PKC} K_{\mathrm{i}}=2.8 \mathrm{nM}$

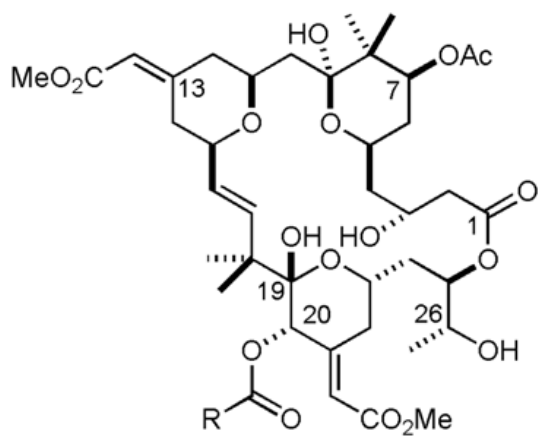

Bryostatin 7: $\mathrm{R}=\mathrm{CH}_{3} ; \mathrm{PKC} K_{\mathrm{i}}=0.84 \mathrm{nM}$ Bryostatin 9: $\mathrm{R}=\mathrm{C}_{3} \mathrm{H}_{7} ; \mathrm{PKC} K_{\mathrm{i}}=1.3 \mathrm{nM}$

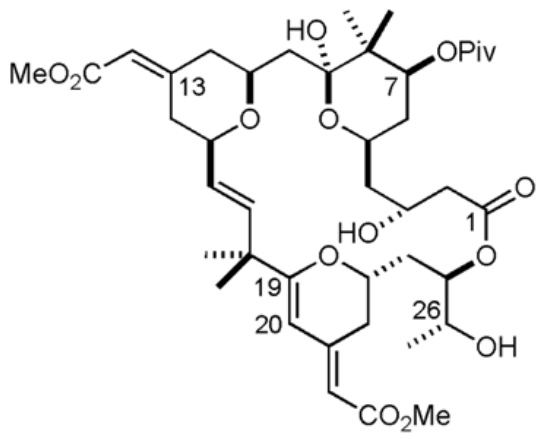

Bryostatin 16: $\mathrm{PKC} \alpha K_{\mathrm{i}}=118 \mathrm{nM}$

Figure 1.

Bryostatins that have been prepared by total synthesis. 
B-ring Dioxane Analogs

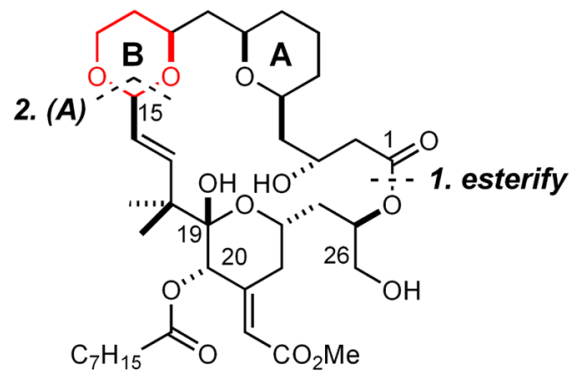

Analog 1: PKC $K_{\mathrm{i}}=3.1 \mathrm{nM}$

A) Macro-acetalization

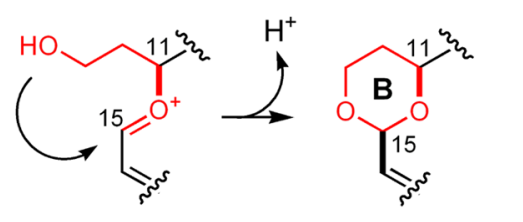

B-ring Pyran Analogs

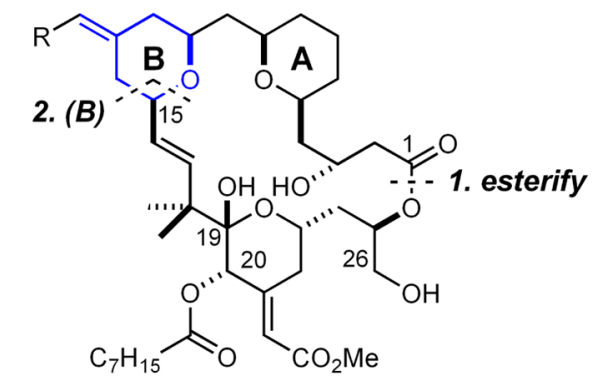

Analog 2: $\mathrm{R}=\mathrm{H} ; \quad \mathrm{PKC} K_{\mathrm{i}}=1.6 \mathrm{nM}$

Analog 3: $\mathrm{R}=\mathrm{CO}_{2} \mathrm{Me} ; \mathrm{PKC} K_{\mathrm{i}}=0.9 \mathrm{nM}$

B) Prins-driven macrocyclization

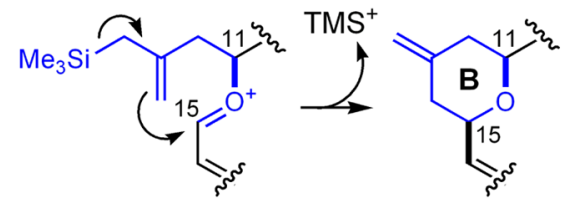

Figure 2.

Representative bryostatin analogs $\mathbf{1}, \mathbf{2}$, and $\mathbf{3}$ and strategies for their synthesis. 


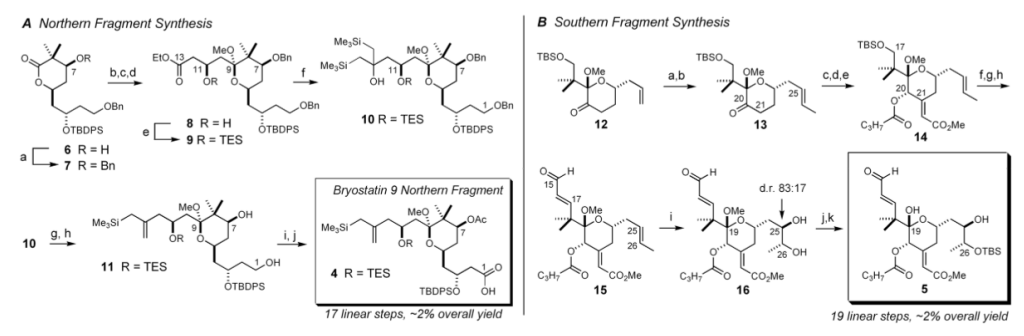

Scheme 1.

Synthesis of the bryostatin 9 northern and southern fragment coupling partners ${ }^{\mathrm{a}}$

${ }^{a}$ A Reagents and Conditions: (a) BnBr, NaHMDS, 5:1 THF:DMF, $0{ }^{\circ} \mathrm{C}$, 90\%; (b) ethyl acetoacetate (2.5 eq.), LDA (5.0 eq.), THF, $-78^{\circ} \mathrm{C}$; (c) PPTS, $\mathrm{MeOH}, 40^{\circ} \mathrm{C}, 84 \%$ over 2 steps; (d) $\mathrm{NaBH}_{4}$, EtOH, $-15^{\circ} \mathrm{C}$, dr: 78:22, 61\% isolated 8; (e) TESCl, imidazole, $\mathrm{CH}_{2} \mathrm{Cl}_{2}$, rt, 97\%; (f) $\mathrm{CeCl}_{3} \cdot 2 \mathrm{LiCl}, \mathrm{TMSCH}_{2} \mathrm{MgCl}$, THF, rt, 65\%; (g) NaHMDS, THF, $0{ }^{\circ} \mathrm{C}, 91 \%$; (h) lithium naphthalenide, THF, $-30{ }^{\circ} \mathrm{C} \rightarrow-10^{\circ} \mathrm{C}, 87 \%$; (i) TEMPO (30 mol \%), PhI(OAc) 2 (3 eq.), 4:1 MeCN:H $2 \mathrm{O}$, then $\mathrm{NaH}_{2} \mathrm{PO}_{4}, \mathrm{NaClO}_{2}, 2$-methyl-2-butene, $0{ }^{\circ} \mathrm{C}$; (j) $\mathrm{Ac}_{2} \mathrm{O}$, DMAP, $\mathrm{CH}_{2} \mathrm{Cl}_{2}, 0{ }^{\circ} \mathrm{C}$, then aq. $\mathrm{NaHCO}_{3}, 57 \%$ over 2 steps. B Reagents and Conditions: (a) $\mathrm{O}_{3}, \mathrm{CH}_{2} \mathrm{Cl}_{2},-78{ }^{\circ} \mathrm{C}$, then $\mathrm{PPh}_{3}, \mathrm{rt}, 98 \%$; (b) $\mathrm{I}_{2} \mathrm{CHCH}_{3}, \mathrm{CrCl}_{2}, \mathrm{DMF}$, THF, $0{ }^{\circ} \mathrm{C}, 76 \%, 93: 7$ E:Z; (c) $\mathrm{K}_{2} \mathrm{CO}_{3}$, methyl glyoxylate, THF: $\mathrm{MeOH}$, rt, $81 \%$; (d) $\mathrm{NaBH}_{4}, \mathrm{CeCl}_{3} \cdot 7 \mathrm{H}_{2} \mathrm{O}, \mathrm{MeOH}$, $-49{ }^{\circ} \mathrm{C}$; (e) butyric anhydride, DMAP, $\mathrm{CH}_{2} \mathrm{Cl}_{2}, \mathrm{rt}, 91 \%$ over 2 steps; (f) $3 \mathrm{HF} \cdot \mathrm{Et}_{3} \mathrm{~N}$, THF, rt; (g) Dess-Martin periodinane, $\mathrm{CH}_{2} \mathrm{Cl}_{2}$, rt; (h) Z-1-bromo-2-ethoxyethylene, $t$-BuLi, $\mathrm{Me}_{2} \mathrm{Zn}$, $\mathrm{Et}_{2} \mathrm{O},-78{ }^{\circ} \mathrm{C}$, then $\mathrm{H}_{3} \mathrm{O}^{+}, 64 \%$ over 3 steps; (i) $\mathrm{K}_{2} \mathrm{OsO}_{4} \cdot 2 \mathrm{H}_{2} \mathrm{O}(\sim 0.5 \mathrm{~mol} \%)$, DHQD $2 \mathrm{PYR}$ $(1.5 \mathrm{~mol} \%), \mathrm{K}_{2} \mathrm{CO}_{3}, \mathrm{~K}_{3} \mathrm{Fe}(\mathrm{CN})_{6}, 4{ }^{\circ} \mathrm{C}, 78 \%, 83: 17(R, R):(S, S)$; (j) $p$-TsOH, $4: 1$

$\mathrm{MeCN}: \mathrm{H}_{2} \mathrm{O}$, rt; (k) TBSCl, imidazole, $\mathrm{CH}_{2} \mathrm{Cl}_{2}, 64 \%$ over 2 steps as a single diastereomer. 


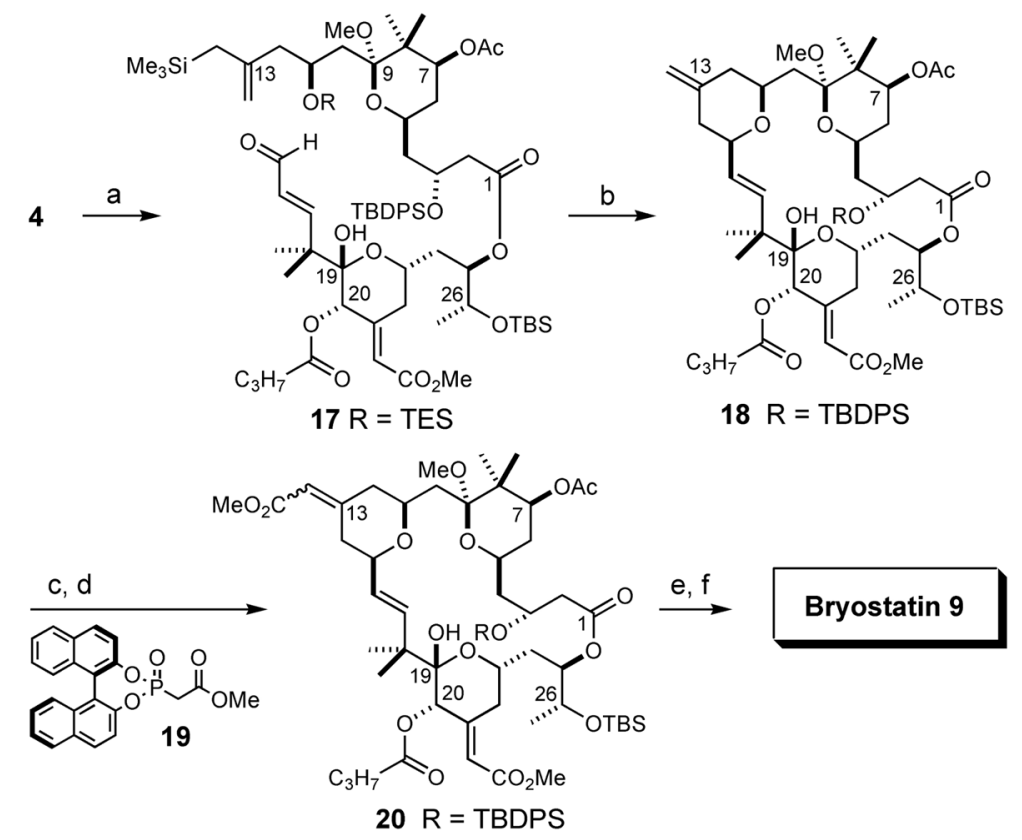

\section{Scheme 2.}

Completion of bryostatin $9^{a}$

${ }^{a}$ Reagents and Conditions: (a) 2,4,6-trichlorobenzoyl chloride, $\mathrm{Et}_{3} \mathrm{~N}, \mathrm{PhCH}_{3}$, then alcohol 5, DMAP, 82\%; (b) PPTS (20 mol \%), $\mathrm{MeOH},[17]=0.02 \mathrm{M}$, rt, $22 \mathrm{~h}, 65 \%$; (c) $\mathrm{O}_{3}, \mathrm{CH}_{2} \mathrm{Cl}_{2}$, $-78{ }^{\circ} \mathrm{C}$, then thiourea, $1: 1 \mathrm{CH}_{2} \mathrm{Cl}_{2}: \mathrm{MeOH}$, rt, $72 \%$; (d) 19, NaHMDS, THF, $-78{ }^{\circ} \mathrm{C} \rightarrow 4$ ${ }^{\circ} \mathrm{C}, 79: 21 \mathrm{Z}: E, 82 \%$; (e) HF.py, THF, rt; (f) PPTS, $20 \% \mathrm{H}_{2} \mathrm{O}$ in THF, rt, $76 \%$ combined yield, 80:20 Z:E, 52\% isolated bryostatin 9 . 